\begin{abstract}
ANEKS
MATERIALY KRZEMIENNE ZE SZCZECINA-PLONI, STANOWISKO 2
\end{abstract}

FLINT ASSEMBLAGES FROM SZCZECIN-PLONIA, SITE 2

\title{
Tadeusz Galiński
}

Instytut Archeologii i Etnologii PAN

ul. Kuśnierska 12A, 70-536 Szczecin, Poland

Z wykopu głównego, składającego się z sektorów I-IX, o łącznej powierzchni ponad $160 \mathrm{~m}^{2}$, wydobyto inwentarz krzemienny liczący 396 zabytków, w tym około 70 rdzeni i narzędzi. Ogromna większość, bo przeszło 75\% materiału, pochodzi ze skupienia osadniczego w sektorach VI-VII; pozostałe zaś z jam obiektów oraz spoza obiektów w środkowej i wschodniej części wykopu (sektory I-V, VIII-IX; ryc. 1).

\section{WYKOP GEÓWNY, SEKTORY VI-VII}

Sektory VI-VII stanowią zachodnią czesść wykopu głównego, którego całkowita powierzchnia wynosi $42,5 \mathrm{~m}^{2}$. Ponad $2 / 3$ powierzchni wykopu zajmował duży obiekt wziemny związany z kulturą neolityczna (obiekt 16), rozcięty w kilku miejscach późniejszymi wkopami osadnictwa wczesnobrązowego. Przy wschodniej krawędzi odsłoniętej części obiektu, w północno-wschodnim narożniku odkrywki, wystąpiło skupisko kamieni (ryc. 1).

Materiał krzemienny zalegał głównie w obrębie obiektu 16 i późniejszych wkopów. Poza nimi, nieco większą koncentrację zabytków krzemiennych odnotowano tylko w bezpośrednim sąsiedztwie skupiska kamieni, gdzie zapewne położona była pracownia krzemieniarska.

\section{Surowiec}

Kilka narzędzi, w tym 4 drapacze i 1 przekłuwacz, a także 1 odłupek, 1 fragment wióra i 1 odpadek wykonane są z krzemienia czekoladowego. Jedno narzędzie (zgrzebło) wykonane jest z rogowca (?). Reszta, tj. 97,02\% materiału, reprezentuje miejscowy krzemień bałtycki, występujący na stanowisku w kilkunastu odmianach i pododmianach. Jedną $z$ odmian stanowi surowiec bardzo charakterystyczny i dość rzadko spotykany, 


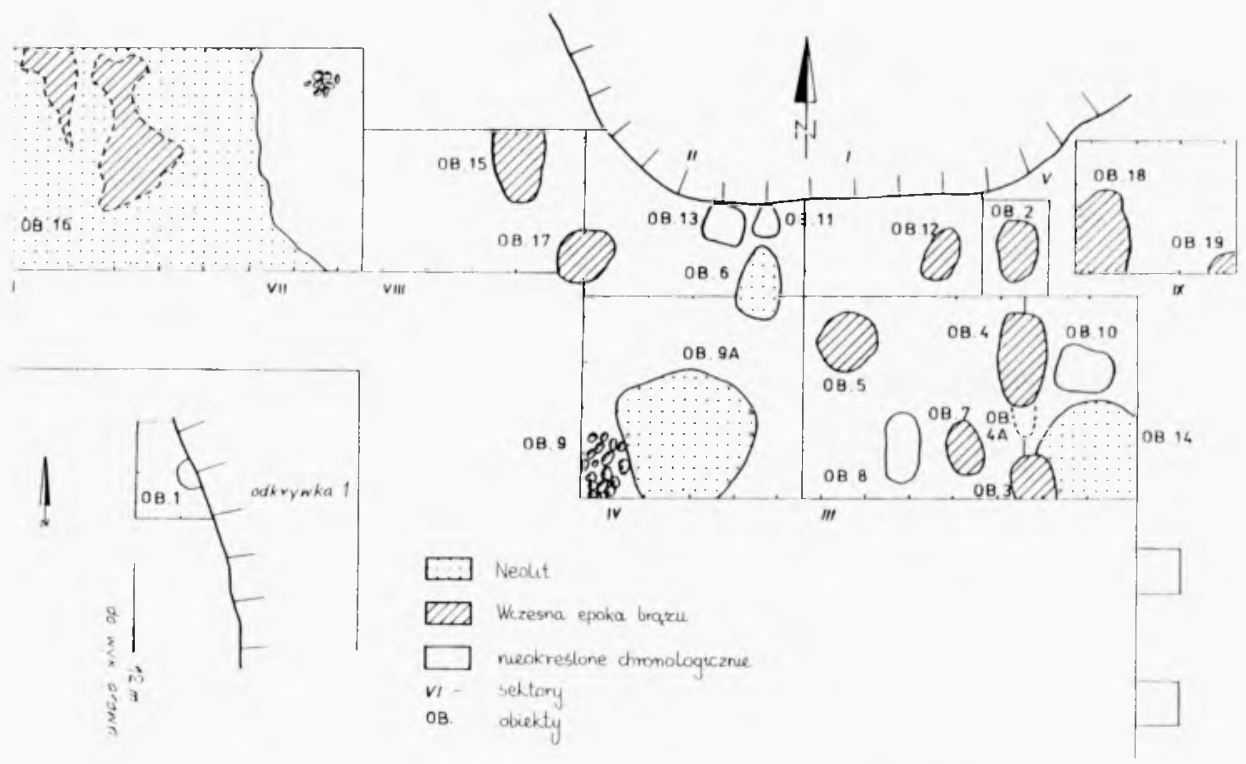

Ryc. 1. Szczecin-Płonia, stan. 2. Planigrafia obiektów w wykopie głównym (sektory l-IX) oraz w odkrywce I Abb. 1. Szczecin-Płonia, Fst. 2. Verteilung der Befunde in der Hauptgrabungsfläche (Sektor I-IX) sowie im Kleinegrabungsfläche 1

o masie zbudowanej z naprzemianległych pasów, charakteryzujących się różną barwa, prześwitem i połyskiem. Można by go określić mianem „pasiasty”. Krzemień ten jest prawdopodobnie pochodzenia jurajskiego, występuje w tutejszych, starszych od zlodowacenia baltyckiego, utworach morenowych.

Na stanowisku znaleziono kilka całych, owalnych konkrecji krzemienia bałtyckiego i kilkadziesiąt ich fragmentów. Największe miały średnicę $12,0 \mathrm{~cm}$, najmniejsze zaś $8,0 \mathrm{~cm}$. Wszystkie charakteryzują się dużym stopniem zniszczenia powierzchni; mają fragmentarycznie zachowaną cienką, zdartą korę, często spękane powierzchnie. Niektóre z nich są minimalnie zgrzane, co może sugerować że były przygotowane do obróbki.

\section{Materiały}

Tabela I

Ogólna struktura inwentarza

\begin{tabular}{l|c|c}
\hline Inwentarz & Liczba & Procent \\
\hline Rdzenie & 23 & 7,62 \\
\hline Luszcznie & 6 & 2,00 \\
\hline Narzędzia & 23 & 7,62 \\
\hline Odłupki & 104 & 34,44 \\
\hline Wióry & 29 & 9,60 \\
\hline Luski, odpady, fragmenty nieokreślone & 72 & 23,84 \\
\hline Konkrecje i fragmenty konkrecji & 45 & 14,90 \\
\hline Razem & 302 & 100,02 \\
\hline
\end{tabular}




\subsection{Rdzenie}

1. Rdzenie dwupiętowe wspólnoodłupniowe - 1; wiórkowy, pięty zaprawiane zbieżne, odlupnia zakolona, tył i boki dzikie. Wymiary: $2,7 \times 2,0 \times 1,6 \mathrm{~cm}$. Okaz zapewne szczątkowy, bardzo silnie wyzyskany.

2. Rdzenie jednopiętowe - 3 (ryc. 5:5); wiórowo-odłupkowe (1) i odłupkowe (2), pięty prostopadłe przygotowane (3), odłupnie zakolone (1) i płaskie (2), ślady zaprawy boków i tyłu (1), ze śladami naprawy odłupni (1). Wymiary ( wysokość $\times$ szerokość $\times$ $\times$ grubość): $4,6 \times 4,2 \times 2,0 \mathrm{~cm} ; 2,6 \times 4,5 \times 3,7 \mathrm{~cm} ; 3,8 \times 5,2 \times 1,6 \mathrm{~cm}$.

3. Rdzenie ze zmianą orientacji - 9; wiórowo-odłupkowe (2) i odłupkowe (7). Średnice rdzeni zawarte sq w przedziale $3,2-6,0 \mathrm{~cm}$.

4. Rdzenie zaczątkowe i fragmenty rdzeni nieokreślonych -10 .

Tabela II

Zestawienie form rdzeni określonych

\begin{tabular}{l|c|c}
\multicolumn{1}{c|}{ Formy rdzeni } & Liczba & Procent \\
\hline Dwupiętowe & 1 & 7,69 \\
\hline Jednopiętowe & 3 & 23,08 \\
\hline Ze zmianą orientacji & 9 & 69,23 \\
\hline Razem & 13 & 100,00 \\
\hline
\end{tabular}

Tabela III

Zestawienie typów rdzeni określonych

\begin{tabular}{l|c|c}
\hline \multicolumn{1}{c|}{ Typy rdzeni } & Liczba & Procent \\
\hline Wiórowe & 0 & 0,00 \\
\hline Wiórkowe & 1 & 7,69 \\
\hline Wiórowo-odłupkowe & 3 & 23,08 \\
\hline Odlupkowe & 9 & 69,23 \\
\hline Razem & 13 & 100,00 \\
\hline
\end{tabular}

\subsection{Luszcznie}

1. Luszcznie dwubiegunowe dwustronne - 1 (ryc. 5:4); wiórowo-odłupkowa o wymiarach $3,2 \times 3,0 \times 1,6 \mathrm{~cm}$.

2. Luszcznie dwubiegunowe jednostronne -1 ; wiórowo-odłupkowa, wymiary: $3,0 \times$ $\times 1,9 \times 0,7 \mathrm{~cm}$.

3. Łuszcznie jednobiegunowe jednostronne - 3; wiórowo-odłupkowe (2) i odłupkowe (1); wymiary: $2,7 \times 2,2 \times 1,2 \mathrm{~cm} ; 2,7 \times 1,6 \times 1,0 \mathrm{~cm} ; 1,5 \times 1,3 \times 1,0 \mathrm{~cm}$.

4. Luszcznie wielobiegunowe dwustronne - 1; odłupkowa o wymiarach 4,6 $\times 3,9 \times$ $\times 1,4 \mathrm{~cm}$.

Tabela IV

Zestawienie form luszczni

\begin{tabular}{l|c|c}
\hline \multicolumn{1}{c|}{ Formy luszczni } & Liczba & Procent \\
\hline Dwubiegunowe & 2 & 33,33 \\
\hline Jednobiegunowe & 3 & 50,00 \\
\hline Wielobiegunowe & 1 & 16,67 \\
\hline Razem & 6 & 100,00 \\
\hline
\end{tabular}




\begin{tabular}{l|c|c}
\multicolumn{3}{c}{ Zestawienie typów łuszczni } \\
\hline \multicolumn{1}{c|}{ Typy łuszczni } & Liczba & Procent \\
\hline Wiórowe & 0 & 00,00 \\
\hline Wiórowo-odłupkowe & 4 & 66,67 \\
\hline Odłupkowe & 2 & 33,33 \\
\hline Razem & 6 & 100,00 \\
\hline
\end{tabular}

\subsection{Pólsurowiec i odpady}

1. Odłupki - 104; odłupki całe -77 , fragmenty odłupków -27 : negatywowe (44), z fragmentami kory (31), korowe (27), techniczne (2).

Wielkość odłupków; od $2,3 \mathrm{~cm}$ do $8,1 \mathrm{~cm}$ średnicy, z modą $3,5-4,0 \mathrm{~cm}$. Nie widać większych różnic metrycznych pomiędzy odłupkami negatywowymi a odłupkami z fragmentami kory i korowymi.

2 . Wióry -29 ; wióry całe -12 , fragmenty wiórów -17 (części z sęczkami -9 , części środkowe - 3, części wierzchołkowe - 5): negatywowe (11), z fragmentami kory (12), korowe (4), techniczne ( 2 - zatępce grzebieniowe jednostronne).

Wielkość wiórów; długość 2,3-5,7 cm, z modą 4,0-4,5 cm; szerokość 1,0-3,1 cm, z modą $1,2-1,8 \mathrm{~cm}$. Wióry o szerokości powyżej $2,0 \mathrm{~cm}$ stanowią procentowo niewielki udzial zbioru i są to wyłącznie wióry $\mathrm{z}$ fragmentami kory i wióry korowe.

3. Łuski, odpady, fragmenty nieokreślone -72 .

4. Konkrecje i fragmenty konkrecji krzemiennych - 45 .

Inwentarz charakteryzuje się zdecydowaną przewaga grupy eksploatacji odłupkowej nad grupą eksploatacji wiórowej, praktycznie przy braku eksploatacji wiórkowej (wiórek $=1<0,8 \mathrm{~cm}$ ). Rdzeń mikrolityczny opisany jako wiórkowy jest jedynym elementem tej grupy technologicznej. Należy jednak zauważyć, że: 1) pozyskany inwentarz jest tylko fragmentem pozostałości osadniczych związanych $\mathrm{z}$ osadnictwem obiektu 16 ;2) w trakcie prac eksploracyjnych nie przesiewano warstw kulturowych i mniejsze elementy wytwórczości krzemieniarskiej, a do takich należą wiórki, mogły zostać nie zauważone.

Wśród rdzeni bardzo wyraźnie dominują formy odłupkowe, przy niewielkim udziale rdzeni wiórowo-odłupkowych i braku rdzeni wiórowych. Panującym w materiale typem rdzenia jest rdzeń ze zmianą orientacji.

Obecność wiórów negatywowych jedno- i dwukierunkowych, relatywnie licznych elementów technicznych związanych z zaprawą rdzeni (m.in. zatępców grzebieniowych jednostronnych) jak i samych rdzeni jednopiętowych dowodzi jednak, że proces produkcji półsurowca rozpoczynał się od eksploatacji rdzeni jednopiętowych i w mniejszym stopniu rdzeni dwupiętowych, i był nastawiony na pozyskiwanie półsurowca wiórowego. Produkowane wióry pierwszych serii (wyniesione poza obręb obozowiska) musiały mieć długość 8,0-6,0 cm, dalszych serii - 5,0-3,0 cm. W końcowym etapie eksploatacji pozyskiwane były już tylko odłupki, a w celu maksymalnego wykorzystania masy surowcowej rdzenie eksploatowano techniką ciagłej zmiany pięty. 


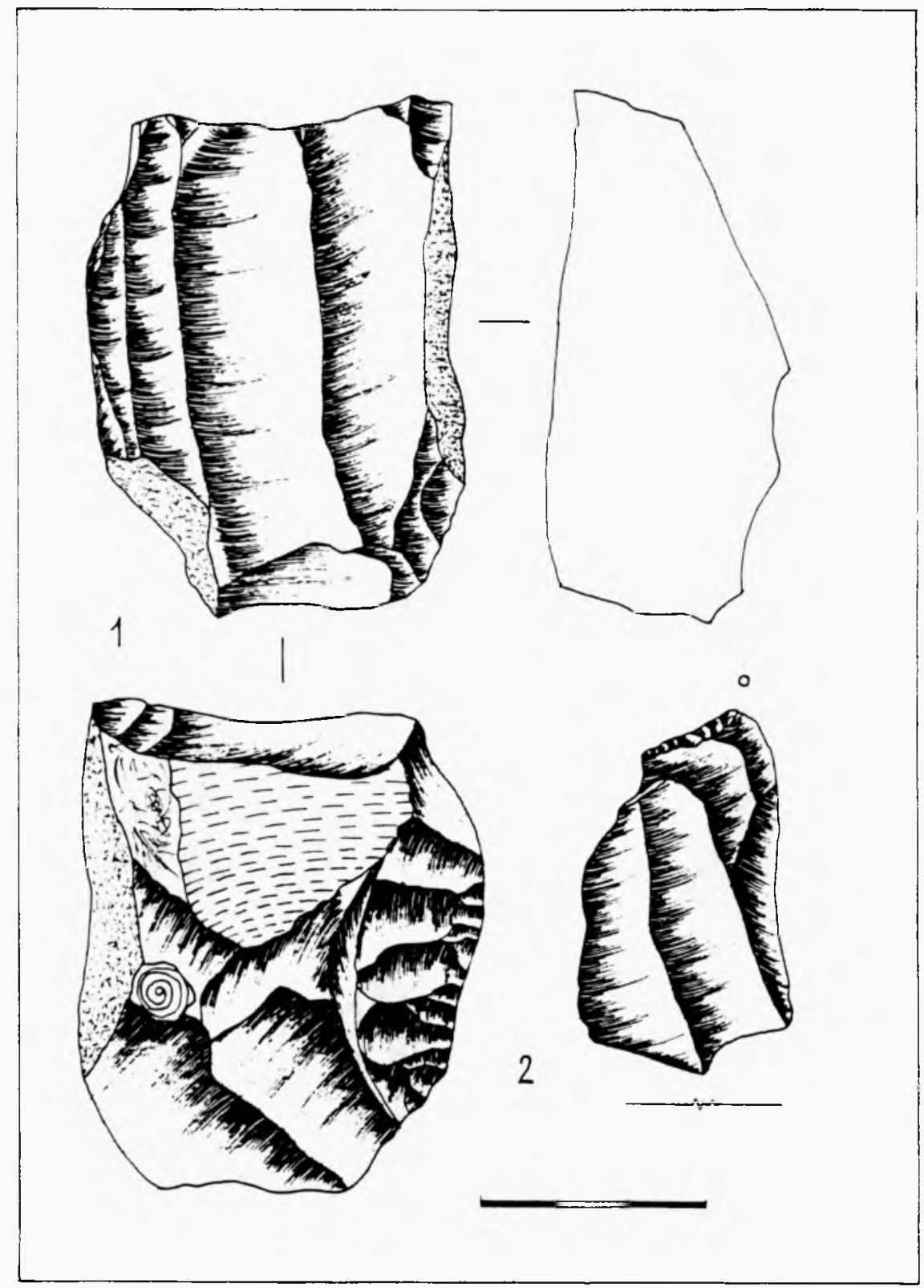

Ryc. 2. Szczecin-Płonia, stan. 2. Rdzeń (1) i półtylczak (2); obiekt 12(1), obiekt 15(2) Abb. 2. Szczecin-Płonia, Fst. 2. Kernstein (1) und Klinge mit schräger Endretusche (2), Grube 12(1), Grube 15(2) 


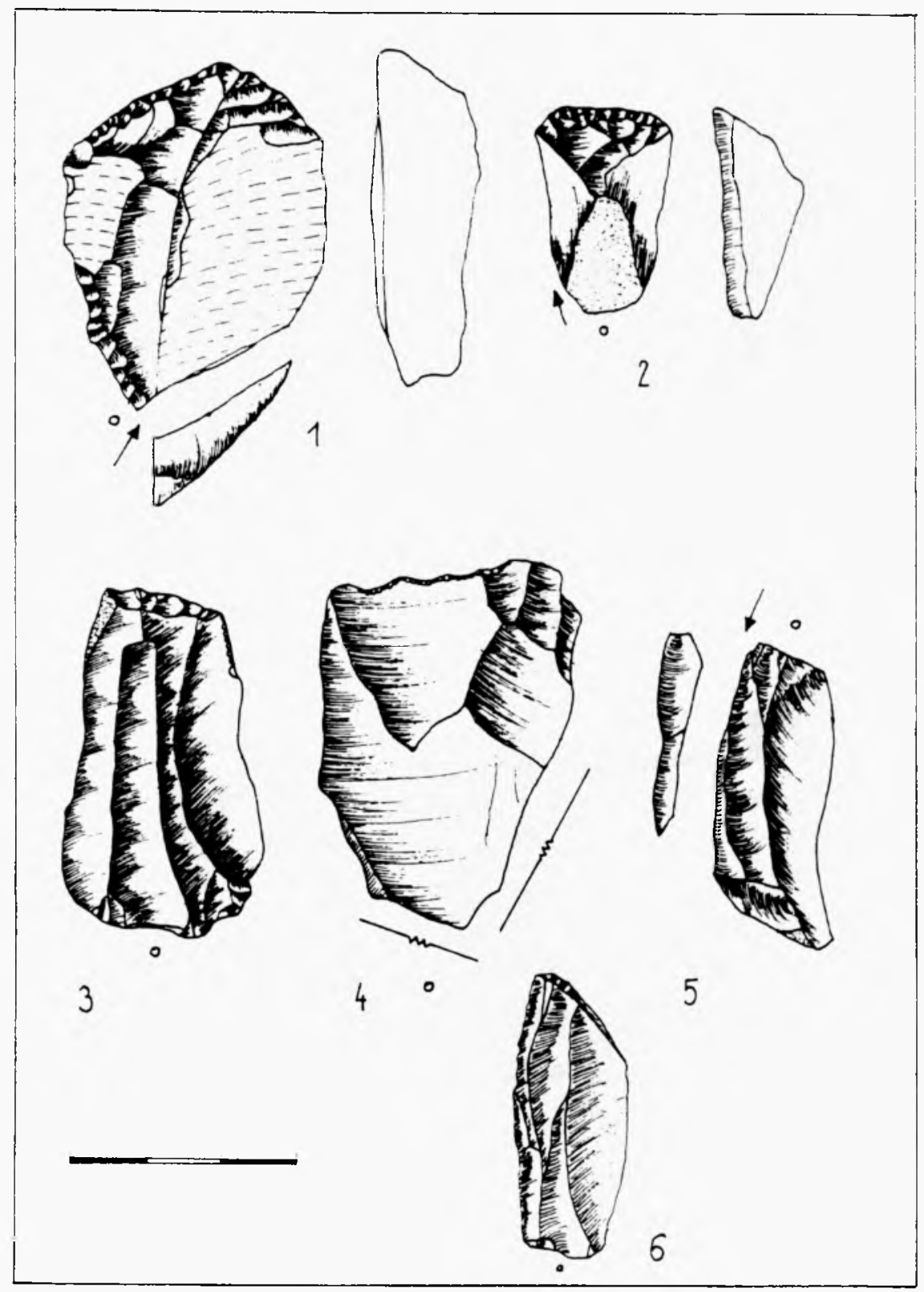

Ryc. 3. Szczecin-Płonia, stan. 2. Drapacze $(1,2)$, półtylczaki $(3,6)$, odłupek huskany (4), rylec (5); obiekt $16(1,2)$, obiekt $4(3,6)$, obiekt $2(4)$, obiekt $1(5)$

Abb. 3. Szczecin-Plonia, Fst. 2. Kratzer (1,2), Klingen mit schräger Endretusche (3, 6); retuschierter Abschlag (4), Stichel (5); Grube 16(1, 2), Grube 4(3,6), Grube 2(4) sowie Grube 1(5) 
Nie do końca jasny jest status występujących w tym materiale łuszczni. Jeżeli bowiem traktować je jako pozostałość produkcji półsurowca, to zastanawiajacy jest zupełny brak tutaj odłupków łuszczniowych. Z kolei zarówno relatywnie duże rozmiary tych wytworów, jak i obecność u nich zawsze ostrej krawędzi może sugerować, że formy te były wykorzystywane jako narzędzia Dotyczy to zwłaszcza 4 spośród 6 łuszczni.

\subsection{Narzędzia}

\section{4a. Drapacze}

1. Drapacze smukłe o drapiskach w różnym stopniu zakolonych i surowych bokach 2 (ryc. 6:3,7); oba wiórowe - pierwszy wykonany z krzemienia czekoladowego.

2. Drapacze krępe o drapiskach w różnym stopniu zakolonych i surowych bokach 6 (ryc. $3: 2$; ryc. $4: 3$; ryc. 5:1; ryc. 6:5,8-9); 4 wiórowe, w tym 3 kurtyzowane, 1 sporządzony $\mathrm{z}$ wióra podtępca, 1 regularyzowany bocznym uderzeniem rylcowym (ryc. 3:2) oraz 2 odłupkowe, w tym 1 duży masywny (ryc. 5:1).

3. Drapacze krępe o drapiskach w różnym stopniu zakolonych i łuskanych bokach 2 (ryc. 6: 1-2); oba wiórowe, kurtyzowane, z krzemienia czekoladowego.

4. Drapacze krótkie zakolone o surowych bokach - 1 (ryc. 6:10); wiórowy, kurtyzowany.

5. Drapacze krótkie zakolone o bokach łuskanych - 1 (ryc. 4:1); masywny, odłupkowy.

6. Drapacze krótkie zdwojone o bokach surowych - 2 (ryc. 5:2; ryc. 6:11); wiórowy i odłupkowy.

\section{4b. Drapaczo-rylce}

1. Drapacz zdwojony z rylcem - 1 (ryc. 3:1); połączenie drapacza zakolonego z rylcem węgłowym środkowym. Okaz sporządzony z grubego odłupka krzemienia czekoladowego.

\section{4c. Rylce}

1. Rylce zwielokrotnione - 1 (ryc. 6:12); połączenie rylca klinowego zboczonego i rylca lamańca. Oba ostrza szerokowierzchołkowe, jedno ze śladami napraw. Narzędzie wykonane z kawałka półsurowiaka albo z grubego odłupka.

\section{4d. Inne narzędzia}

1. Zgrzeblo z grubego, masywnego odłupka (ryc. 4:4); retusz stromy, wysoki. Surowiec: rogowiec?

2. Skrobacz jednoboczny z odłupka (ryc. 6:6); łuskanie strome, wysokie.

3. Przekłuwacz o delikatnym, nie wydzielonym żądle, sporządzony $z$ wióra łamanego dołem (ryc. 6:4); wierzchołek uszkodzony. Krzemień czekoladowy.

4. Fragment środkowej części płoszcza typu Płonia (ryc. 7: 1); okaz pierwotnie miał długość około $15,5 \mathrm{~cm}$, szerokość w środkowej partii $-4,5 \mathrm{~cm}$, grubość $-1,0 \mathrm{~cm}$. 
5. Duży odłupek - fragment siekierki krzemiennej.

6. Duży, masywny odłupek łuskany fragmentarycznie.

Analiza surowcowa, technologiczna i typologiczna materiałów krzemiennych sektora VI wykopu głównego wskazuje jednoznacznie, że nie są one zwarte chronologicznie i kulturowo. Ogromna większość $\mathrm{z}$ nich stanowi pozostałość osadnictwa neolitycznego (KCWR). Natomiast przynajmniej kilka wyrobów można z pewnością przypisywać osadnictwu wczesnobrązowemu. Należą do nich przede wszystkim: płoszcz typu Płonia (ryc. 7:1) - planigraficznie zalegał w strefie wkopu w obiekt 16, masywny drapacz odłupkowy (ryc. 4:1) - wystapił poza obiektem na granicy sektora VII i VIII oraz łuszcznie - strefa wkopu w obiekt 16.

\section{WYKOP GLÓWNY, SEKTORY I-V, VIII-IX}

W środkowej i wschodniej części wykopu głównego materiały krzemienne występowały nielicznie i w dużym rozproszeniu, poza obiektami oraz w obiektach (ryc. 1).

\section{Surowce}

Opisywane tu materiały wykonane są w całości z miejscowego krzemienia bałtyckiego, w tym również ze wspomnianego wyżej surowca ,pasiastego".

\section{Obiekty}

Obiekt 2. Rdzeń ze zmianą orientacji wiórowo-odlupkowy, o średnicy $4,1 \mathrm{~cm}$, częściowo zniszczony, zgrzany; duży odłupek łamany intencjonalnie na dwóch bokach i łuskany fragmentarycznie (ryc. 3:4); wiór łamany intencjonalnie na obu końcach, z delikatnym łuskaniem krawędzi bocznej (ryc.4:2); 8 odłupków, w tym 5 całych i 3 fragmenty; poza jednym, który jest duży, o średnicy $6,0 \mathrm{~cm}$, reszta mieści się w przedziale $2,3-3,8 \mathrm{~cm}$. Wśród odhupków znajdują się okazy z fragmentami kory (3) i negatywowe (5).

Opisywany materiał pochodzi od 3 do 4 różnych konkrecji krzemienia bałtyckiego, przy czym nie ma wzajemnej zgodności surowcowej pomiędzy formami wydzielonymi. $Z$ rdzeniem wiąże się co najwyżej 1 odłupek.

Obiekt 4. Półtylczaki wiórowe - 2; oba skośne łuskane 3/4 stromo, wysoko (ryc. 3:3; ryc. 3:6 uszkodzony); 6 całych odłupków, w tym 1 zatępiec grzebieniowaty jednostronny, 4 odłupki z fragmentami kory i 1 negatywowy, których wielkość zawiera się w przedziale $2,2-6,5 \mathrm{~cm}$.

Żaden $\mathrm{z}$ odłupków nie wykazuje zgodności surowcowej z półtylczakami, które wykonane zostały $z$ dwóch różnych konkrecji krzemienia bałtyckiego - pierwszy (ryc. 3:3) z dobrej jakości krzemienia przypominającego surowiec jurajski. Same odłupki pochodzą przynajmniej od trzech różnych konkrecji battyckich. 


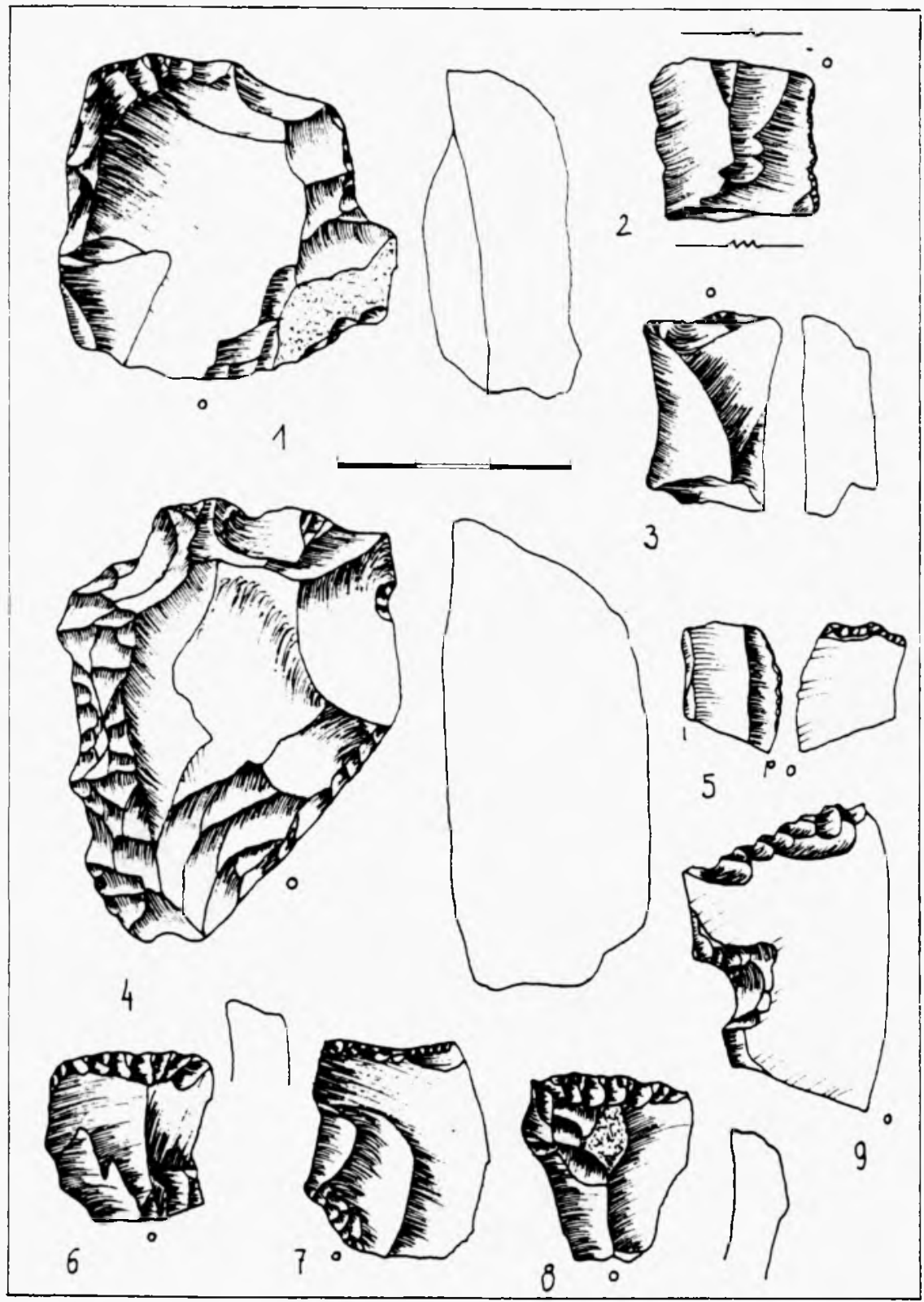

Ryc. 4. Szczecin-Płonia, stan. 2. Drapacze $(1,3,6,8)$, wiór łamany z retuszem boku (2), zgrzebło (4), półtylczaki $(5,7)$, narzędzie wnękowe (9); sektor VI $(1,3,4)$, obiekt $2(2)$, obiekt $5(5)$, obiekt $15(6,7)$, obiekt $14(8,9)$

Abb. 4. Szczecin-Płonia, Fst. 2. Kratzer (1, 3,6, 8), zerbrochene Klinge mit Seitenretusche (2), Rechtwinkelschaber (4), Klingen mit schräger Endretusche (5, 7), Gerät mit Kerbe (9); Sektor VI (1, 3, 4), Grube 2(2), Grube 5(5), Grube $15(6,7)$, Grube $14(8,9)$ 

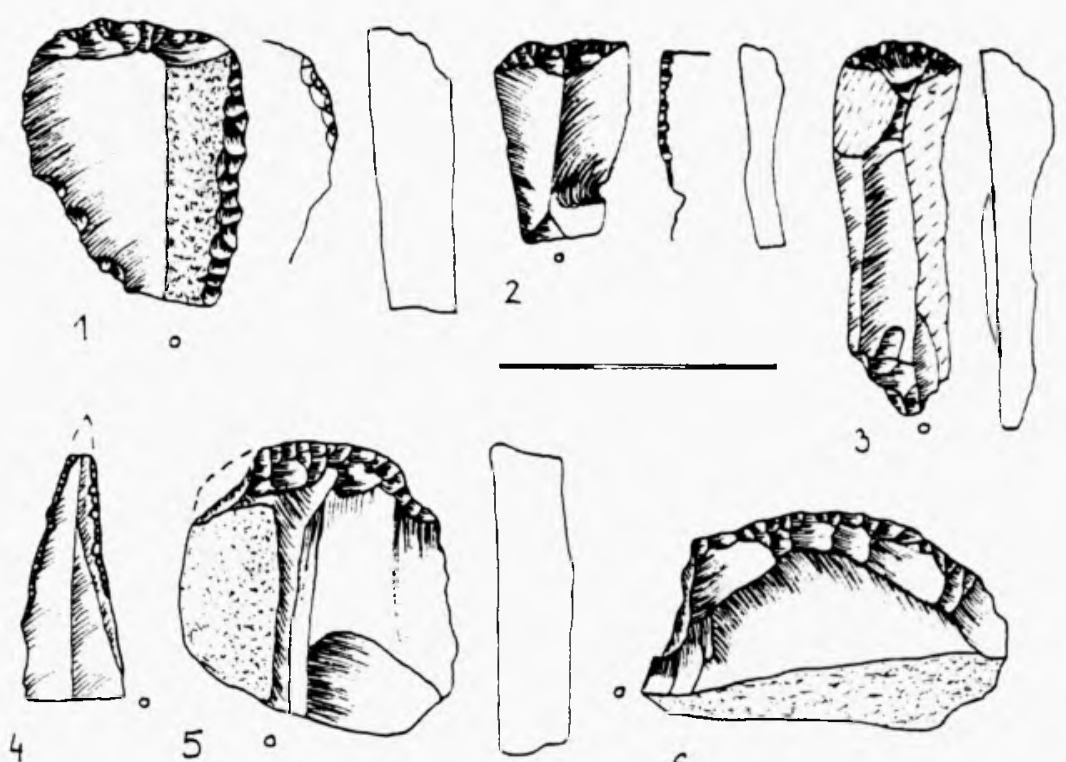

3
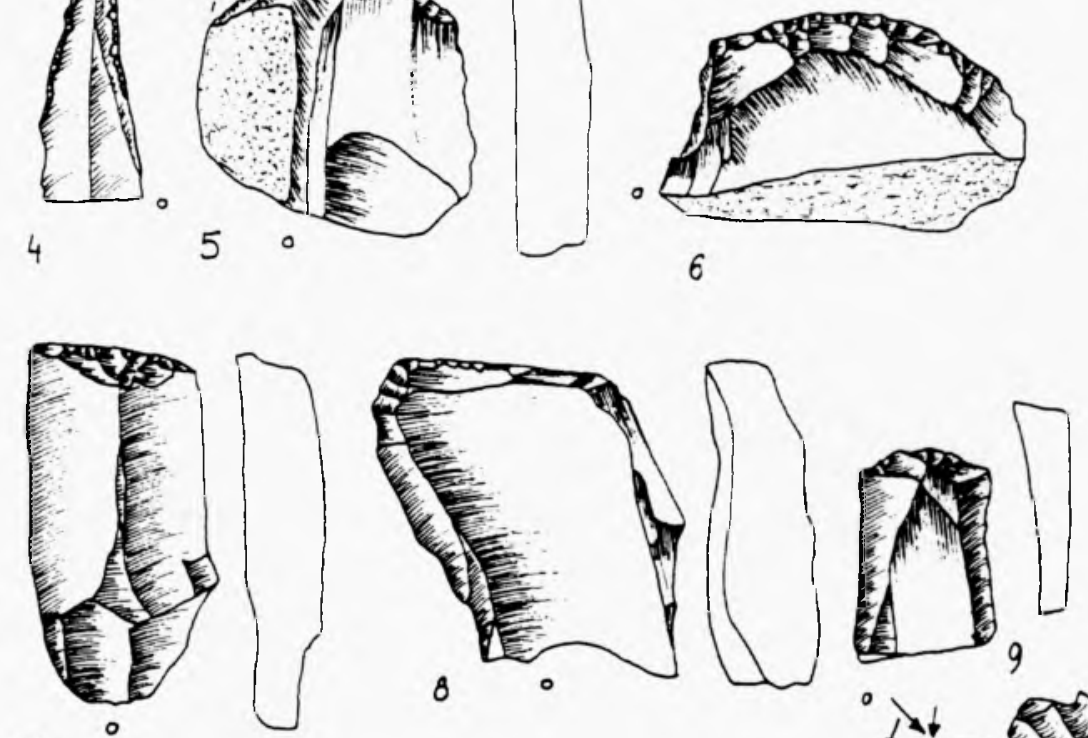

7
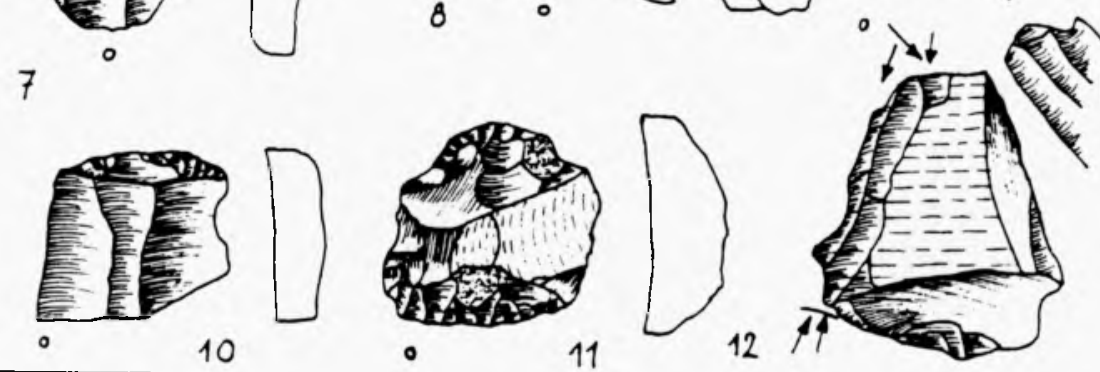

Ryc. 5. Szczecin-Płonia, stan. 2. Drapacze (1, 2), rdzenie (3, 5), łuszcznia (4); obiekt $16(1,2,5)$, obiekt 13(3), sektor VI(4)

Abb. 5. Szczecin-Plonia, Fst. 2. Kratzer (1, 2), Kernsteine (3, 5), Abschlagsplitter (4); Grube 16(1, 2, 5), Grube 13(3), Sektor VI(4) 
Obiekt 5. Półtylczak wiórowy poprzeczny, łuskany na stronę spodnią (ryc. 4:5) ułamany; 2 duże odłupki o średnicy $5,2 \mathrm{~cm} \mathrm{i} 6,5 \mathrm{~cm}$ - techniczny ze śladami zaprawy rdzenia i negatywowy. Wszystkie różne pod względem surowcowym, wykonane z krzemienia bałtyckiego.

Obiekt 6A. Fragment narzędzia bliżej nieokreślonego; wiór lamany intencjonalnie na obu końcach; 5 odłupków, w tym 2 całe i 3 fragmenty; 3 wióry - 1 cały i 2 fragmenty. Wśród odłupków znajdują się korowe (1), z fragmentami kory (3) i negatywowe (1). Ich wielkość zawarta jest w przedziale 3,5-6,0 cm średnicy. Wióry są korowe (1) i negatywowe (2), o parametrach metrycznych: długość $5,0 \mathrm{~cm}$, szerokość $2,0-2,3 \mathrm{~cm}$.

Materiał ten pochodzi od przynajmniej trzech różnych konkrecji krzemienia bałtyckiego.

Obiekt 7. Fragment wióra z krzemienia bałtyckiego.

Obiekt 8. Odłupek łuskany fragmentarycznie, duży, o średnicy $5,2 \mathrm{~cm}$; odpadek techniczny. Oba wyroby z krzemienia bałtyckiego.

Obiekt 12. Regularny rdzeń jednopiętowy płaski z pochyloną do tyłu piętą - wiórowy, pięta zaprawiana, ślady zaprawy boków i tyłu, wymiary: $6,4 \mathrm{~cm} \times 5,1 \mathrm{~cm} \times 3,0 \mathrm{~cm}$ (ryc. 2:1); 2 odłupki - 1 cały i 1 fragment.

Wszystkie trzy zabytki pochodzą od innych konkrecji krzemienia bałtyckiego.

Obiekt 13. Rdzeń jednopiętowy stożkowaty - wiórowy, pięta prostopadła zaprawiana, odłupnia obejmuje $3 / 4$ obwodu rdzenia, wymiary $4,1 \mathrm{~cm} \times 4,0 \mathrm{~cm}$ (ryc. 5:3); 3 małe odłupki - wszystkie zachowane w całości: korowe (1), z fragmentami kory (1), negatywowe (1); 2 fragmenty konkrecji.

Materiał pochodzi od przynajmniej trzech różnych konkrecji krzemienia bałtyckiego.

Obiekt 14. Drapacz krępy zakolony o bokach surowych - kurtyzowany z odłupka (ryc. 4:8); narzędzie wnękowe sporządzone $z$ dużego odłupka - jedna krawędź łuskana zębato (ryc. 4:9); odłupek łuskany fragmentarycznie; 5 całych odłupków, w tym 4 korowe i 1 negatywowy - ich średnice zawarte są w przedziale 2,7-5,3 cm; 1 wiór zachowany w calości o wymiarach: długość $4,0 \mathrm{~cm}$, szerokość $2,0 \mathrm{~cm}$.

Materiał jest niejednolity pod względem surowcowym; pochodzi od przynajmniej 5 różnych konkrecji, przy czym zdecydowana większość od 3 różnych konkrecji, wśród których znajduje się charakterystyczny, miejscowy krzemień morenowy „pasiasty".

Obiekt 15. Drapacz krępy zakolony o bokach surowych - z wióra (ryc. 4:6); półtylczak skośny wykonany z szerokiego wióra łamanego dołem (ryc. 2:2); półtylczak odłupkowy poprzeczny (ryc. 4:7); łuszcznia jednobiegunowa jednostronna, odłupkowa.

Zabytki wykonane są z różnych konkrecji krzemienia baltyckiego.

Obiekt 18. Odłupki - 2; korowy i negatywowy. Oba pochodzą od różnych konkrecji krzemienia bałtyckiego. 


\section{Materiały spoza obiektów}

Odłupki - 17, w tym 11 całych i 6 fragmentów: negatywowe (4), z fragmentami kory (8), korowe (5); fragmenty wiórów - 1; odpady i fragmenty nieokreślone - 8; fragmenty konkrecji - 9.

Według obserwacji poczynionych przez Autorkę badań na stanowisku, poszczególne obiekty wziemne położone w środkowej i wschodniej części wykopu reprezentują dwie różne chronologicznie i kulturowo fazy osadnictwa: obiekty $6 \mathrm{~A}$ i 14 ( jamy) związane są z neolitycznym osadnictwem (KCWR), natomiast obiekty 2, 4, 5, 12, 15, 18 to groby cmentarzyska wczesnobrązowego tzw. fazy płońskiej. Wynika stąd problem interpretacji materiałów krzemiennych występujących w opisanych obiektach, zwłaszcza w grobach wczesnobrązowych, które jako młodsze posadowione zostały na terenie wchodzącym wcześniej w obszar funkcjonowania osadnictwa neolitycznego.

Generalnie trzeba powiedzieć, że pod względem surowcowym, technologicznym i typologicznym materiały wydobyte ze środkowej i wschodniej części wykopu nie odbiegają od materiałów z sektorów VI-VII, i w zdecydowanej większości wiążą się z osadnictwem neolitycznym. Dotyczy to również większości krzemieni występujących w obiektach wczesnobrązowych.

Przedmioty krzemienne, które możemy pewnie uznać za element wyposażenia grobowego w obiektach płońskich sq następujące:

obiekt 4 - dwa półtylczaki wiórowe (ryc. 3:3.6),

obiekt 5 - półtylczak wiórowy (ryc. 4:5),

obiekt 15 - półtylczak wiórowy (ryc. 2:2), łuszcznia.

\section{Odkrywka 1}

Obiekt 1. Rylec jedynak podłużny wąskowierzchołkowy wykonany z wióra (ryc. 3:5); fragment siekierki krzemiennej. Zabytki zostały sporządzone z różnych konkrecji krzemienia bałtyckiego.

\section{KRZEMIENIARSTWO NEOLITYCZNE (KCWR)}

W świetle analizy materiałów krzemiennych, obiekt nr 16 w sektorze VI wykopu głównego jawi się jako obiekt mieszkalny. W jego bezpośrednim sąsiedztwie od strony wschodniej znajdowała się niewielka pracownia przydomowa produkcji krzemieniarskiej (skupienie w sektorach VI-VII). Rozrzucone w dużym rozproszeniu niewielkie ilości materiału krzemiennego na obszarze środkowej i wschodniej części wykopu głównego, gdzie również występują luźne obiekty wziemne o charakterze gospodarczym, w naturalny sposób zakreślaja przestrzeń, na której funkcjonowalo osadnictwo. W świetle wydobytych źródel, miało ono najpewniej charakter jednofazowy i niezbyt trwały w czasie.

Obecość w materiale krzemiennym znikomej ilości krzemienia czekoladowego (ok. $1,5 \%)$ i to w postaci wyłącznie gotowych wyrobów może sugerować, że zostały one 

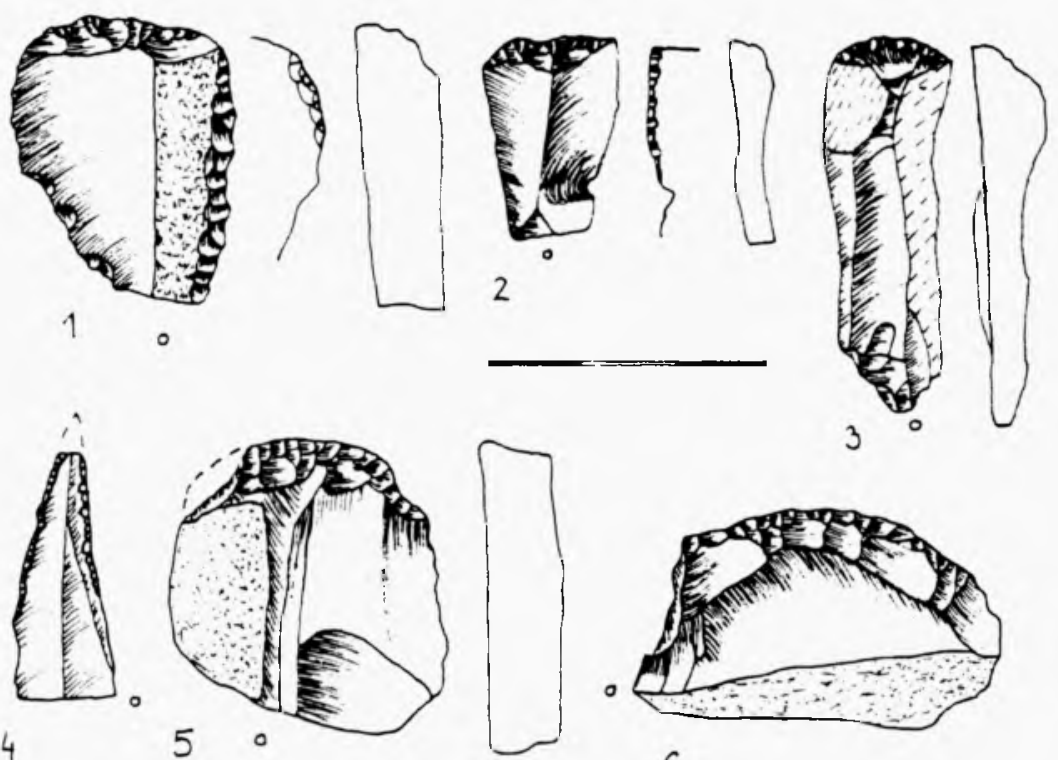

3
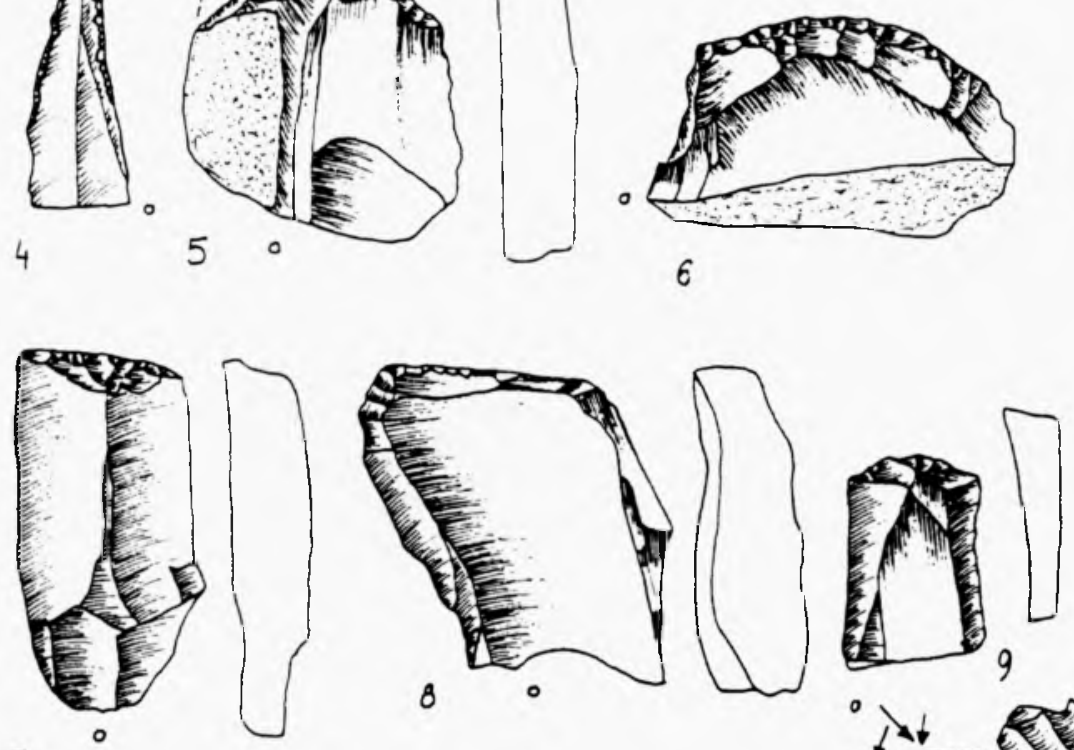

7
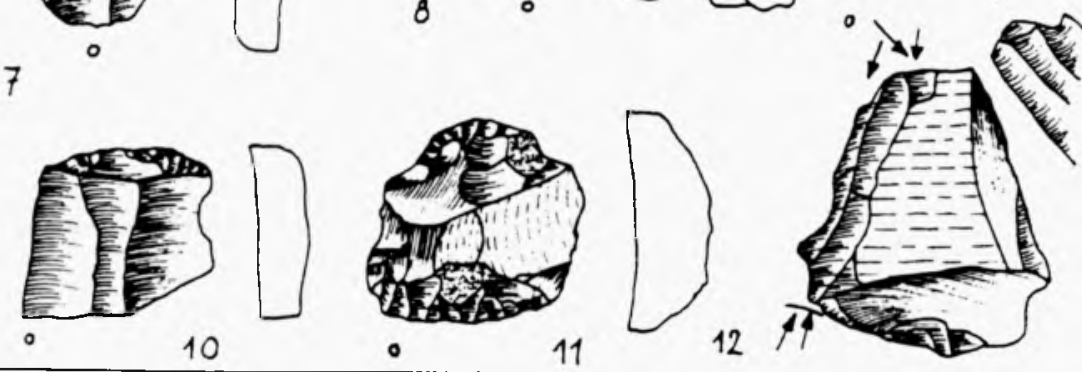

Ryc. 6. Szczecin-Plonia, stan. 2. Drapacze (1-3, 5, 7-11), przekłuwacz (4), skrobacz (6), rylec (12); obiekt $16(1)$, sektor VI (2-12)

Abb. 6. Szczecin-Płonia, Fst. 2. Kratzer (1-3,5,7-11), Bohrer (4), Schaber (6), Stichel (12); Grube $16(1)$, Sektor VI (2-12) 


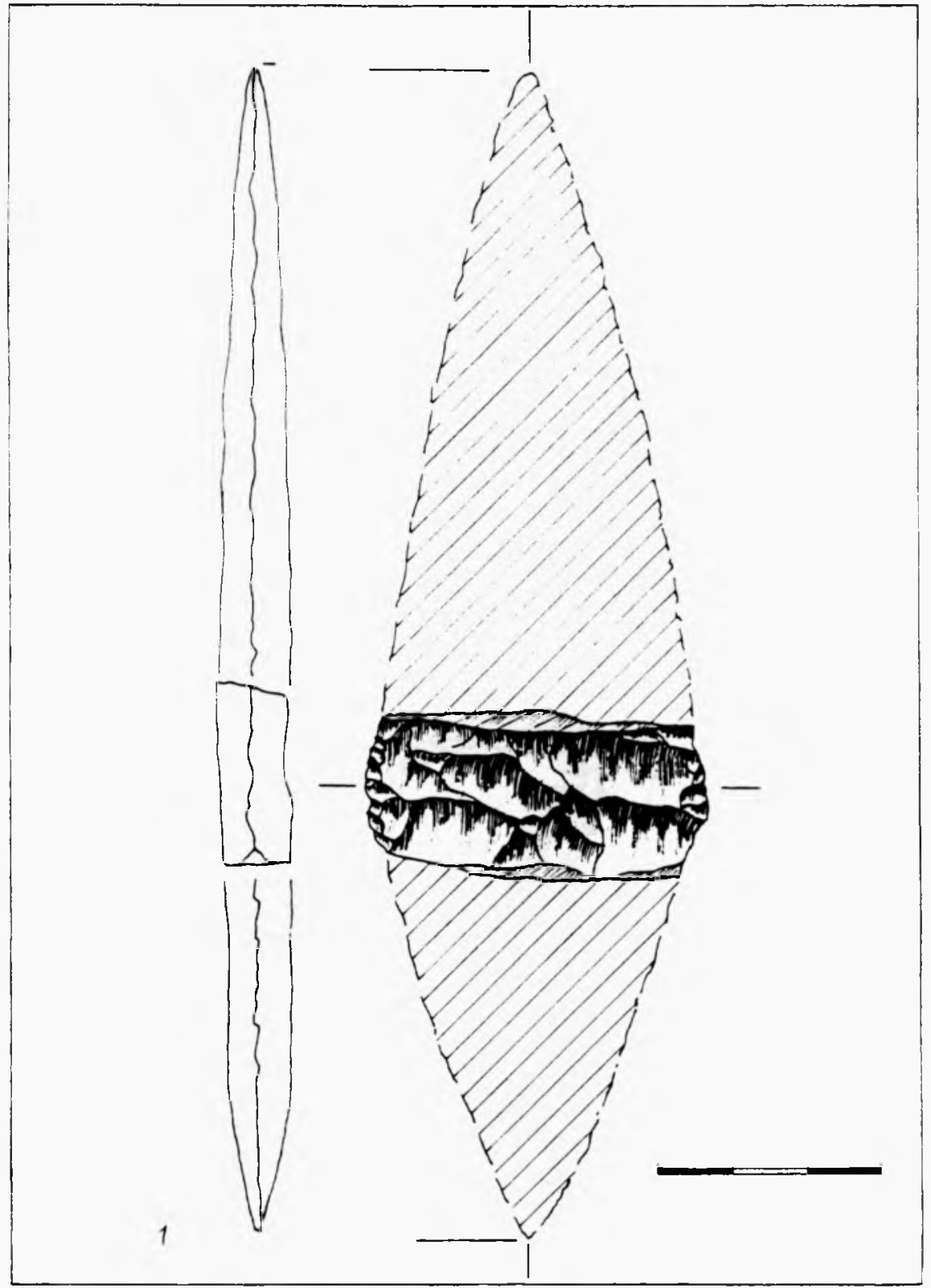

Ryc. 7. Szczecin-Płonia, stan. 2. Płoszcz typu Płonia; sektor VI(1) Abb. 7. Szczecin-Plonia, Fst. 2. Lanzenspitze vom Typ Plonia; Sektor VI(1) 
przyniesione na stanowisko $w$ momencie zasiedlania terenu. Tak czy inaczej zabytki te sa dowodem jakiejś łączności mieszkającej tu grupy ludzkiej z odległymi terenami Polski południowej.

Producja krzemieniarska mieszkańców stanowiska bazowała na miejscowych surowcach krzemiennych, wydobywanych z okolicznych złóż morenowych. Przynoszone do obozowiska konkrecje były stosunkowo małe $(8,0-12,0 \mathrm{~cm}$ średnicy). Może to oznaczać, że przybysze niezbyt dobrze orientowali się w lokalnych możliwościach zdobycia krzemiennej masy surowcowej. Godzi się tu zauważyć, że w młodszych zespołach neolitu pomorskiego powszechnie wykorzystywane były buły krzemienne o średnicy dochodzacej do $30 \mathrm{~cm}$.

W przypadku tych niezbyt okazałych bryłek surowca, stosowano jednak pełną zaprawę przygotowawczą rdzenia, co musiało wiązać się z dużą determinacją chęci pozyskiwania w miarę regularnego półsurowca wiórowego. Nie rezygnowano jednak też z produkcji odłupków, wykorzystując maksymalnie do końca masę surowcową bardziej udanych konkrecji.

Ogólna struktura technologiczna inwentarza, w której wyraźnie dominuje eksploatacja odlupkowa, jest tylko jednym $z$ aspektów obrazu pozostałości produkcji krzemieniarskiej. Innym jest fakt, że główny przedmiot tej produkcji, jakim byl półsurowiec wiórowy, w różnej postaci i różnych celach został wyniesiony poza obręb badanego siedliska.

$Z$ półsurowca tego wyrabiane były m.in. takie narzędzia, jak drapacze. Spośród wydobytych na stanowisku 15 okazów (włączając również okazy znalezione poza skupieniem w sektorach VI-VII), aż 12 z nich $(80,0 \%)$ wykonanych zostało ze średnich i szerokich wiórów; $1,5-2,9 \mathrm{~cm}$, ze średnią $2,23 \mathrm{~cm}$. W tej liczbie aż $33,3 \%$ to wióry zatępce i podtępce, a dalszych $33,3 \%$ to wióry korowe i z fragmentami kory.

Dla całej grupy narzędziowej odsetek wiórów wykorzystanych jako półsurowiec produkcyjny wynosi $66,7 \%$. Bardzo wymowna jest ogólna struktura grupy narzędzi, w której kluczową pozycję zajmują drapacze, stanowiąc aż ponad 68\% (tab. VI).

Tabela VI

Struktura ogólna grupy narzędziowej

\begin{tabular}{l|c|c}
\hline \multicolumn{1}{c|}{ Grupa narzędziowa } & Liczba & Procent \\
\hline Drapacze & 15 & 68,18 \\
\hline Drapaczo-rylce & 1 & 4,54 \\
\hline Ryłce & 1 & 4,54 \\
\hline Zgrzebła & 1 & 4,54 \\
\hline Skrobacze & 1 & 4,54 \\
\hline Póltylczaki & 1 & 4,54 \\
\hline Przekłuwacze & 1 & 4,54 \\
\hline Narzędzia wnękowe & 22 & 4,54 \\
\hline Razem & & 99,96 \\
\hline
\end{tabular}


Poza drapaczami ujawniona została obecność rylców, zgrzebeł, skrobaczy, półtylczaków wiórowych, przekłuwaczy i narzędzi wnękowych. Niestety, w materiałach zabrakło tzw. zbrojników, czyli grotów strzał. Nie zmienia to jednak faktu, że taki obraz grupy narzędziowej wybitnie charakteryzuje osadnictwo związane funkcjonalnie $z$ łowiectwem. Toteż i w przypadku omawianego stanowiska można przynajmniej powiedzieć, że produkcja krzemieniarska była w znaczącym, jeżeli nie w decydującym stopniu, związana właśnie $\mathrm{z}$ łowiectwem leśnym.

\section{KRZEMIENIARSTWO WCZESNOBRĄZOWE TZW. FAZY PLOŃSKIEJ}

Cmentarzysko $\mathrm{z}$ tzw. fazy płońskiej zostało posadowione na terenie użytkowanym wcześniej przez grupy neolityczne i w jamach grobowych znalazły się wtórnie neolityczne wyroby krzemienne. Niezależnie jednak od tego, w niektórych obiektach stwierdza się występowanie wytworów krzemiennych jako elementu wyposażenia grobowego. Taką pewność mamy w przypadku przynajmniej trzech grobów: obiekty 4, 5 i 15. Mniej pewna jest sytuacja przedmiotów krzemiennych występujących w obiektach (grobach) 2 i 12.

Jako element wyposażenia grobowego występowały tu półtylczaki wiórowe, łuszcznie oraz ewentualnie wiór łamany intencjonalnie na obu końcach $\mathrm{z}$ retuszem boku (ryc. 4:2) i wytwór w postaci regularyzowanego odłupka $z$ łuskaniem poprzecznej w stosunku do osi krawędzi, który można ostatecznie sklasyfikować również jako póttylczak (ryc. 3:4). Być może w grę wchodzą tu jeszcze dwa duże odłupki z grobu 5.

Poza obiektami grobowymi materiały krzemienne plońskie zalegały w jamach (wkopach) niewiadomego przeznaczenia, w obrębie sektora VI. Chodzi tu o płoszcz typu Płonia oraz łuszcznie. Opisane wytwory, choć nieliczne i wyrywkowe, dość klarownie rysują ogólny obraz krzemieniarstwa płońskiego. Jego zasadnicze cechy to: wykorzystywanie regularnych, średnich i szerokich $(1,6-2,8 \mathrm{~cm}$ ) wiórów oraz dużych (ponad $5,0 \mathrm{~cm}$ średnicy) odłupków; stosowanie techniki intencjonalnego kawalkowania półsurowca; pozyskiwanie półsurowca techniką rdzeniową i techniką luszczniową; wykorzystywanie łuszczni jako narzędzi; stosowanie techniki rdzeniowej w obróbce narzędziowej; ważne miejsce półtylczaków wiórowych, masywnych drapaczy odłupkowych i płoszczy Płonia w grupie narzędzi.

Krzemieniarstwo płońskie oparte było na eksploatacji miejscowych, morenowych złóż surowca, wykorzystując przy tym duże, do $25 \mathrm{~cm}$ średnicy, buły krzemienne. 